\title{
The Cost of Health Care in Serbia According to the International Classification of Diseases for the Period from 2004 to 2009
}

\author{
Milena Gajić-Stevanović ${ }^{1}$, Snežana Dimitrijević ${ }^{1}$, Slavoljub Živković2 ${ }^{2}$ Nevenka Teodorović2 \\ Darinka Perišić-Rajnicke 3 \\ "Institute of Public Health of Serbia "Dr Milan Jovanović Batut", Belgrade, Serbia; \\ ${ }^{2}$ School of Dentistry, University of Belgrade, Belgrade, Serbia; \\ ${ }^{3}$ CITY College, University of Sheffield, Belgrade, Serbia
}

\begin{abstract}
SUMMARY
Introduction As the part of research on costs in the health care system, there is a growing interest in the world for the estimating costs for the treatment of disease. This value represents the burden that a particular disease or group of diseases puts on the society. Until the year 2000, when the Organization for Economic Countries Development (OECD) established a System of Health Accounts (SHA), there was not even approximate methodological guide for calculating the cost of the disease. The aim of this study was to determine the costs of health care in the Republic of Serbia according to the major International Classification of Diseases (ICD-10) and to provide a comparative cost analysis for the treatment of diseases in the period from 2004 to 2009.

Material and Methods A retrospective and comparative analysis of health statistics from the database of the Institute of Public Health of Serbia and financial information provided by the Health Insurance Fund in the period 2004-2009 was performed. Financial information and data on hospital services, outpatient, home health care, ancillary health care services, drug consumption and consumer goods in healthcare were analyzed using SHA methodology.

Results Results showed that during the observation period, the maximum cost of health care in Serbia by main classification of ICD-10 was achieved in 2009 and it was RSD 144,150,456,906.00 (€1,503,321,134; $\$ 2,160,253,219)$ and the minimal cost was achieved in 2004 - the amount being RSD 49,546,211,470.00 ( $€ 628,086,723 ; \$ 855,203,134)$. Results showed that in 2004 the highest costs were allocated to circulatory diseases (18.98\%), followed by neoplasm (11.12\%), and lowest for congenital anomalies (0.64\%). In 2009, the highest costs were allocated to circulatory diseases (18.87\%), infectious and parasitic diseases (11.20\%), diseases of digestive system (9.26\%) nervous system diseases ( $9.20 \%)$, and neoplasm (8.88\%), whereas the minimal funds were allocated for congenital anomalies (0.33\%).

Conclusion Comparative analysis showed that the value of overall spending in healthcare increased three times in 2009 as compared to 2004.
\end{abstract}

Keywords: International Classification of Diseases; health spending; cost of illness

\section{INTRODUCTION}

As the part of research about the cost of health care system, there has been a growing interest worldwide over the last ten years in estimating the cost of illness [1-7] with most of studies covering only particular diseases [8-16], injuries [17], disorders [18] or conditions [19-24]. Their expressed value represents the burden that a particular disease or group of diseases puts on the society [5]. The first studies related to the cost of treatment of a disease or group of diseases occurred in 1950s, but until 2000, when the Organization for Economic Development countries (OECD) established a "system of health care", there was no methodological framework for calculating the operating cost of the particular illness.
Table 6 in the System of Health Accounts (SHA) [25], as the part of National Health Accounts (NHA), shows a running costs of health care by main groups of diseases according to the International Classification of Diseases (ICD-10), here presented in Table 1.

In SHA health care costs by ICD-10 categories are defined as all those costs in health system that do not include prevention, public health services, health administration, health insurance, as well as functions related to health care.

The aim of this study was to determine the cost of health care in Serbia by main groups of the ICD-10, and to allow comparative analysis of cost for the treatment of the group of diseases in the period from 2004 to 2009. 


\section{MATERIAL AND METHODS}

Retrospective and comparative analysis of health statistics from the Institute of Public Health of Serbia (IPH) database and financial data from the National Health Insurance Fund (NHIF) in the period from 2004 to 2009 was performed. Financial information and data on hospital services, outpatient, home health care, ancillary health care services, drug consumption and consumer goods in health were analyzed according to the methodology of NHA and the OECD manual, SHA Version 1.0.

Health care costs of the population of Serbia by the main ICD-10 categories were calculated according to the following NHA schedule and OECD methodology:

- H.C.1. Hospital services are financially expressed by the number of hospital days (hd.) according to the disease groups (source: Institute of Public Health of Serbia) multiplied with the price of the current HIF Price List for hospital services [26].

- H.C.1.2. Day care services are not registered by groups of diseases (no data).

Table 1. Groups of diseases according to the International Classification of Diseases (ICD-10) using the methodology for table 6 SHA on the basis SHA Version 1.

Tabela 1. Raspodela grupa oboljenja prema Međunarodnoj klasifikaciji bolesti (MKB) po metodologiji za izradu tabele 6 NZR na osnovu SZR (verzija 1).

\begin{tabular}{|c|c|}
\hline $\begin{array}{l}\text { Code } \\
\text { Šifra }\end{array}$ & $\begin{array}{l}\text { Groups of diseases } \\
\text { Grupe oboljenja }\end{array}$ \\
\hline A00-B99 & $\begin{array}{l}\text { Infectious and parasitic diseases } \\
\text { Infektivne i parazitske bolesti }\end{array}$ \\
\hline C00-D48 & $\begin{array}{l}\text { Neoplasm } \\
\text { Tumori }\end{array}$ \\
\hline E00-E90 & $\begin{array}{l}\text { Endocrine and metabolic diseases } \\
\text { Endokrine i bolesti metabolizma }\end{array}$ \\
\hline D50-D89 & $\begin{array}{l}\text { Blood diseases } \\
\text { Bolesti krvi }\end{array}$ \\
\hline F00-F99 & $\begin{array}{l}\text { Mental disorders } \\
\text { Mentalni poremećaji }\end{array}$ \\
\hline G00-G99 & $\begin{array}{l}\text { Diseases of the nervous system } \\
\text { Bolesti nervnog sistema }\end{array}$ \\
\hline $100-199$ & $\begin{array}{l}\text { Vascular diseases } \\
\text { Bolesti krvotoka }\end{array}$ \\
\hline J00-J99 & $\begin{array}{l}\text { Respiratory diseases } \\
\text { Bolesti disajnog sistema }\end{array}$ \\
\hline K00-K93 & $\begin{array}{l}\text { Digestive diseases } \\
\text { Bolesti digestivnog sistema }\end{array}$ \\
\hline N00-N99 & $\begin{array}{l}\text { Diseases of the genitourinary system } \\
\text { Bolesti urogenitalnog sistema }\end{array}$ \\
\hline O00-099 & $\begin{array}{l}\text { Complications of pregnancy/childbirth } \\
\text { Komplikacije trudnoće i porođaja }\end{array}$ \\
\hline L00-L99 & $\begin{array}{l}\text { Skin and subcutaneous tissue diseases } \\
\text { Bolesti kože i potkožnog tkiva }\end{array}$ \\
\hline M00-M99 & $\begin{array}{l}\text { Diseases of the musculoskeletal system } \\
\text { Bolesti mišićno-koštanog sistema }\end{array}$ \\
\hline Q00-Q99 & $\begin{array}{l}\text { Congenital anomalies } \\
\text { Urođene anomalije }\end{array}$ \\
\hline P00-P96 & $\begin{array}{l}\text { Perinatal conditions } \\
\text { Perinatalna stanja }\end{array}$ \\
\hline R00-R99 & $\begin{array}{l}\text { Symptoms and pathological conditions } \\
\text { Simptomi i patološka stanja }\end{array}$ \\
\hline S00-T98 & $\begin{array}{l}\text { Injuries, poisoning and consequences } \\
\text { Povrede, trovanja i posledice }\end{array}$ \\
\hline V01-Z99 & $\begin{array}{l}\text { All other categories } \\
\text { Sve ostale kategorije }\end{array}$ \\
\hline
\end{tabular}

- H.C.1.3. Financial resources spent for outpatient patients treatment by ICD-10 were obtained by multiplying the number of outpatient treatment services (source: Institute of Public Health of Serbia) with the price of the current HIF Price List for health services.

- H.C.1.4. Home health services were expressed as home services treatment (data source table planning for health, which deal with the Institute of Public Health of Serbia) multiplied by the price of the current HIF Price List for health services.

- H.C.4. Ancillary health care services (laboratory, diagnostic and patient transportation) are financially expressed by the empirically estimated total number of services by groups of diseases, and then multiplied by the respective prices of the current HIF Price List for health services.

- H.C.5.1. Financial statements on items "Drugs and other consumer goods" according to groups of diseases by ICD-10, were obtained from the Drugs and Medical Devices Agency of Serbia.

Collected items H.C.1., H.C.1.2., H.C.1.3., H.C.1.4., H.C.4. and H.C.5.1., by groups of diseases express the estimated financial value of the total cost of health care for diseases according to the ICD-10.

The comparative and retrospective methods of research were used for the analysis.

When making this analysis, the data from the Republican Statistical Office (RSO) and the National Bank of Serbia (NBS) were applied.

\section{RESULTS}

The results have determined the costs for health care by main ICD-10 groups (Table 2). The results are shown in Graphs 1-12 with a special analysis for each year.

The analysis showed that total cost for health care by main ICD-10 categories in 2004 amounted 49,546,621,147.00 RSD (€ 628,086,723; \$ 855,203,134). By groups of diseases the highest costs were allocated to circulatory diseases $(18,98 \%)$, followed by neoplasm (11.12\%) and diseases of urogenital system (10.02\%), where the minimal funds were allocated for congenital anomalies $(0.64 \%)$ and prenatal conditions $(0.86 \%)$ (Graphs 1 and 2). Health care expenditures by main

Table 2. Total costs for health care according to the ICD-10 groups in Serbia from 2004 to 2009

Tabela 2. Ukupni troškovi zdravstvene zaštite prema grupama MKB u Srbiji u periodu 2004-2009. godine

\begin{tabular}{|c|c|c|c|}
\hline \multirow{2}{*}{$\begin{array}{c}\text { Year } \\
\text { Godina }\end{array}$} & \multicolumn{3}{|c|}{$\begin{array}{c}\text { Total costs } \\
\text { Ukupni troškovi }\end{array}$} \\
\cline { 2 - 4 } & $\begin{array}{c}\text { In RSD } \\
\text { U dinarima }\end{array}$ & $\begin{array}{c}\text { In Euros } \\
\text { U evrima }\end{array}$ & $\begin{array}{c}\text { In US Dollars } \\
\text { U dolarima }\end{array}$ \\
\hline 2004 & $49,546,621,147.00$ & $628,086,723$ & $855,203,134$ \\
\hline 2005 & $81,222,190,366.00$ & $949,967,138$ & $1,124,666,678$ \\
\hline 2006 & $96,162,554,246.00$ & $1,217,247,522$ & $1,603,358,597$ \\
\hline 2007 & $120,987,502,236.00$ & $1,526,922,066$ & $2,251,868,727$ \\
\hline 2008 & $142,398,620,728.00$ & $1,607,189,769$ & $2,263,889,041$ \\
\hline 2009 & $144,150,456,906.00$ & $1,503,321,134$ & $2,160,253,219$ \\
\hline
\end{tabular}

Source: NBS and PHIS

Izvor: NBS i IZIZS 


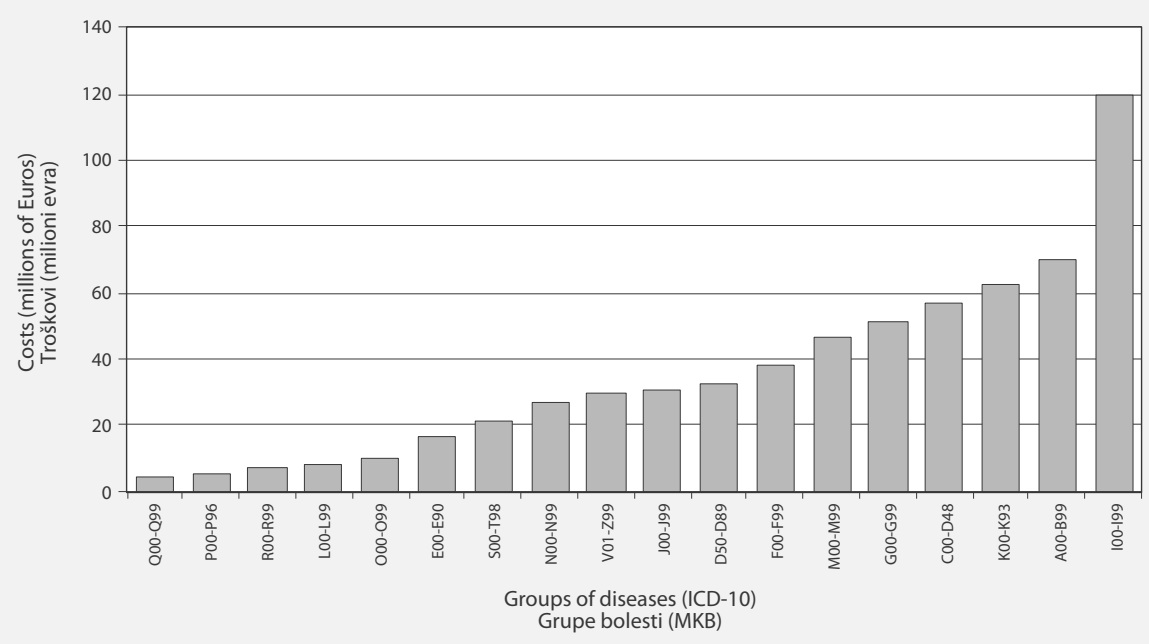

Source: Republican Statistical Office (RSO), National Bank of Serbia (NBS) and Institute of Public Health of Serbia (IPHS) Izvor: Republički zavod za statistiku (RZS), Narodna banka Srbije (NBS) i Institut za javno zdravlje Srbije (IZIZS)

Graph 1. Costs in Euros for healthcare by ICD-10 groups in 2004

Grafikon 1. Troškovi zdravstvene zaštite prema grupama oboljenja MKB u 2004. godini izraženi u evrima

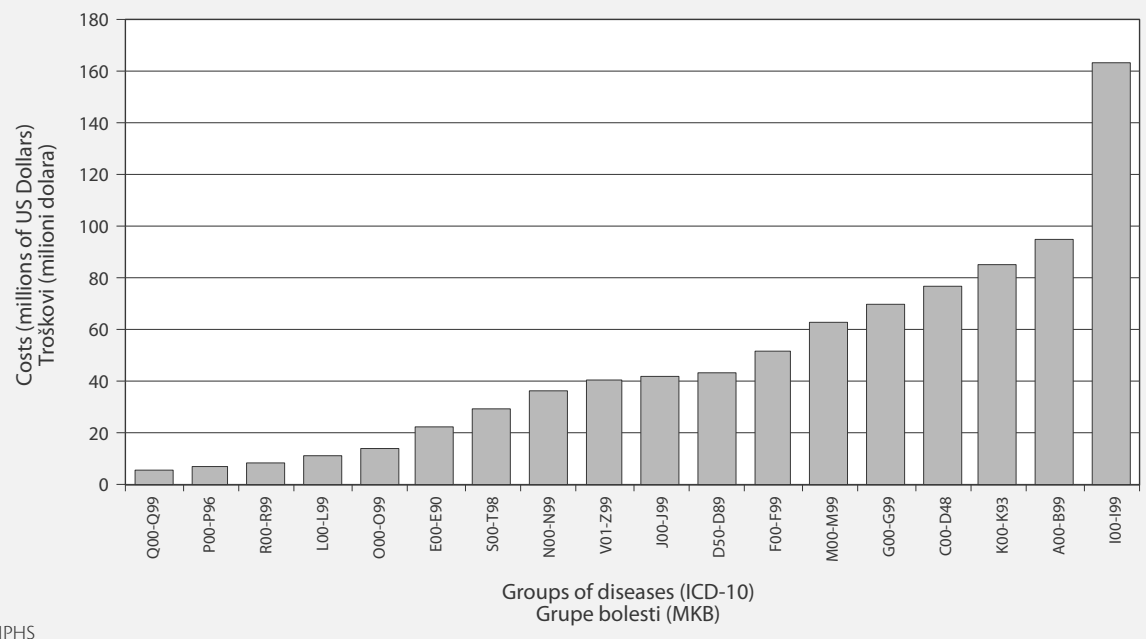

Graph 2. Costs in US dollars for healthcare by ICD-10 groups in 2004

Grafikon 2. Troškovi zdravstvene zaštite prema grupama oboljenja MKB u 2004. godini izraženi u američkim dolarima

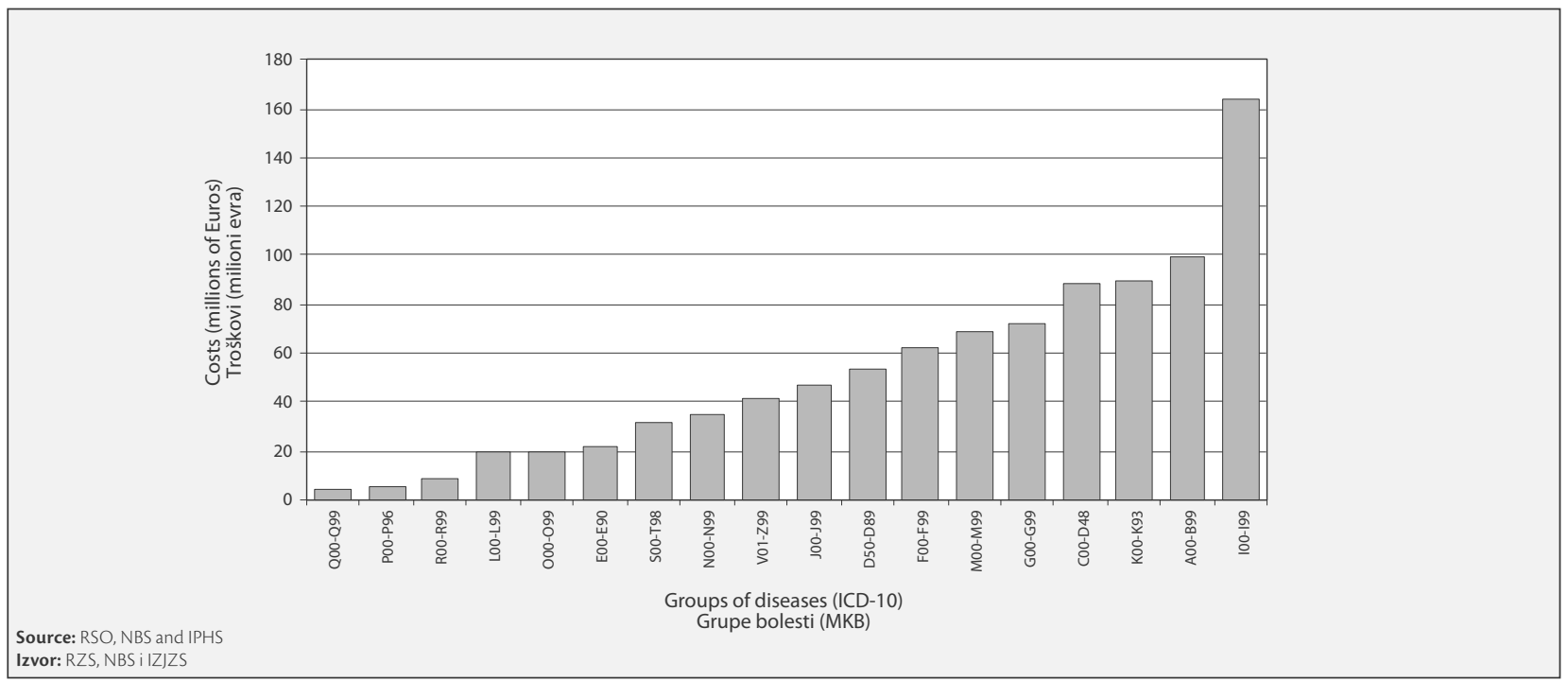

Graph 3. Costs in Euros for healthcare by ICD-10 groups in 2005

Grafikon 3. Troškovi zdravstvene zaštite prema grupama oboljenja MKB u 2005. godini izraženi u evrima 


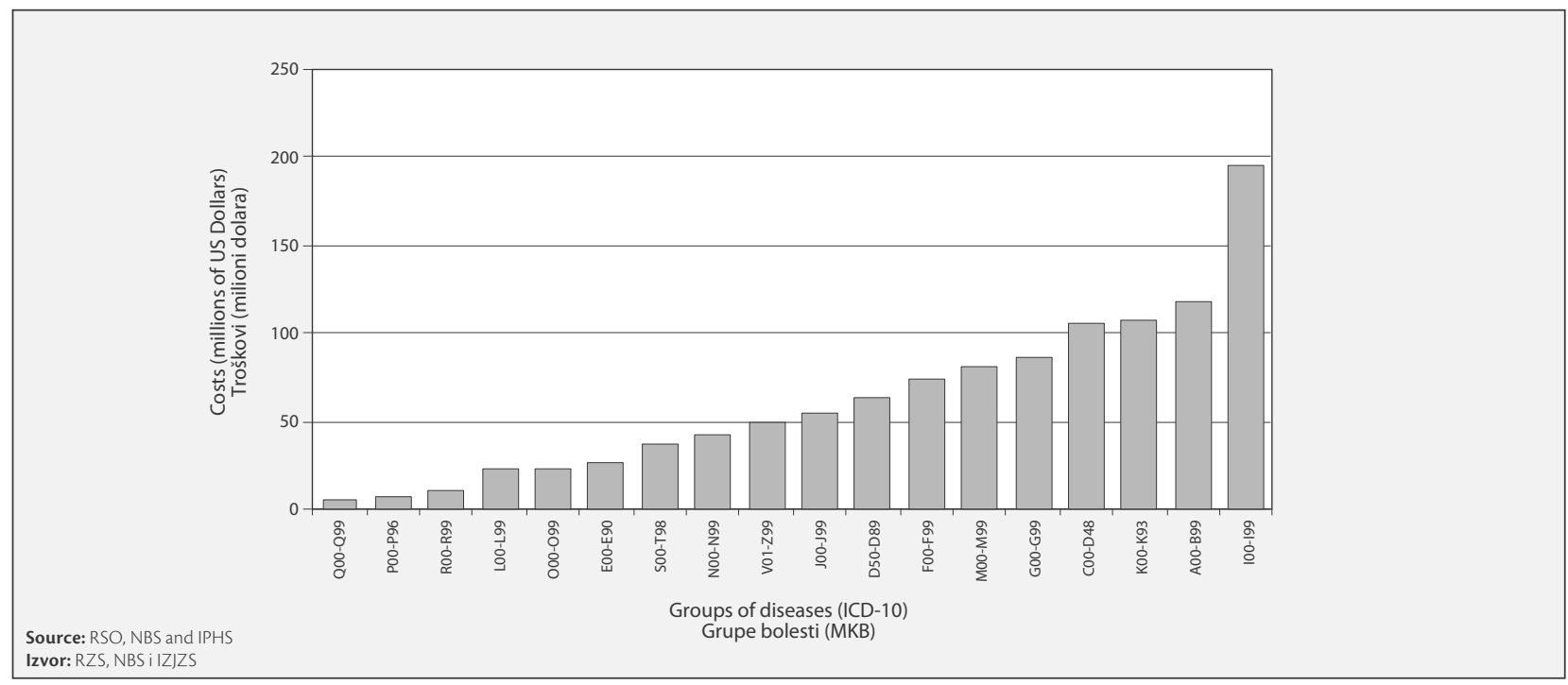

Graph 4. Costs in US dollars for healthcare by ICD-10 groups in 2005

Grafikon 4. Troškovi zdravstvene zaštite prema grupama oboljenja MKB u 2005. godini izraženi u američkim dolarima

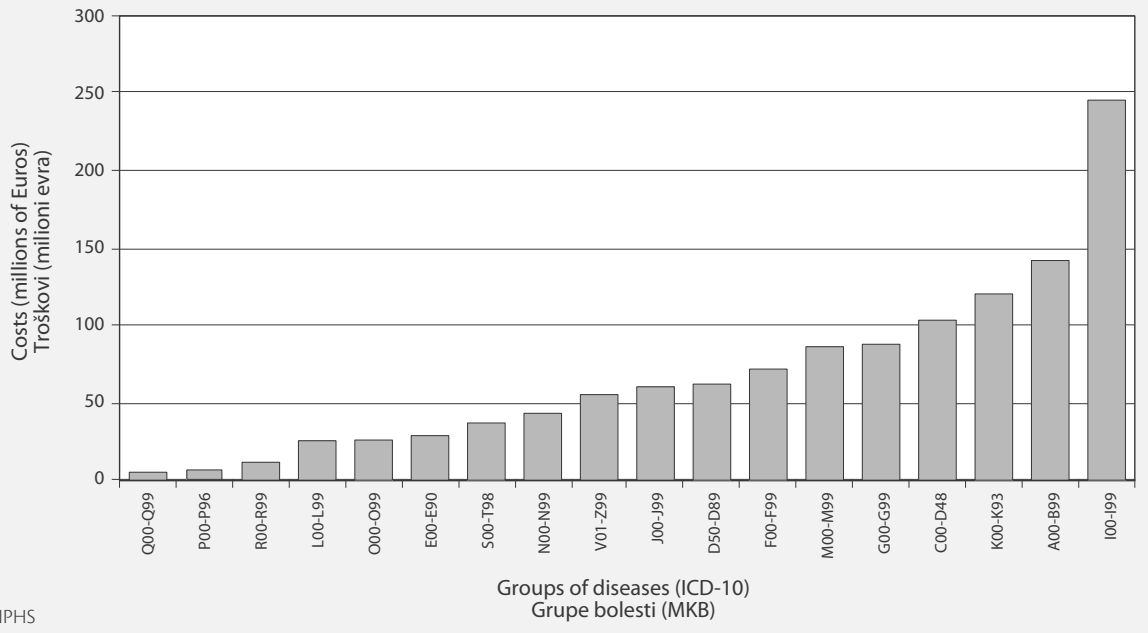

Source: RSO, NBS and IPH

Graph 5. Costs in Euros for healthcare by ICD-10 groups in 2006

Grafikon 5. Troškovi zdravstvene zaštite prema grupama oboljenja MKB u 2006. godini izraženi u evrima

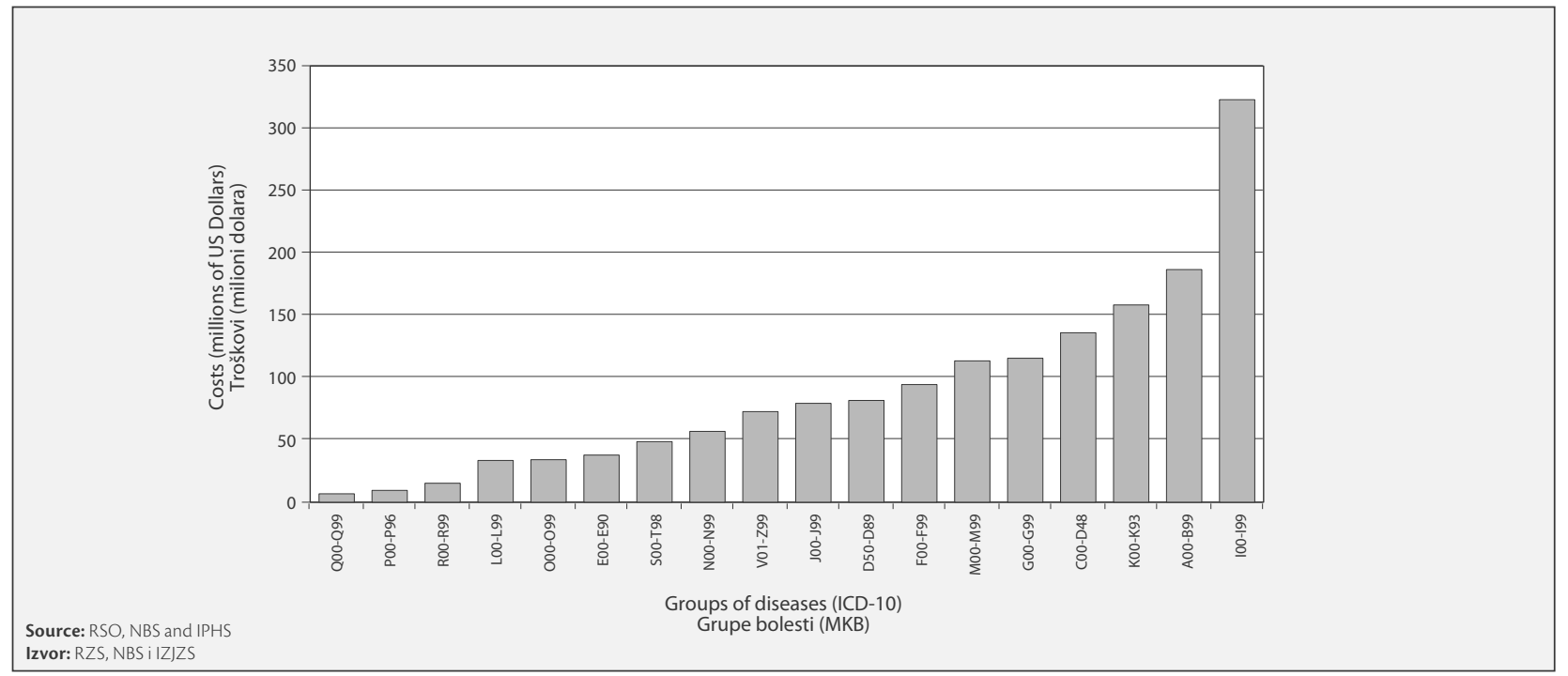

Graph 6. Costs in US dollars for healthcare by ICD-10 groups in 2006

Grafikon 6. Troškovi zdravstvene zaštite prema grupama oboljenja MKB u 2006. godini izraženi u američkim dolarima 


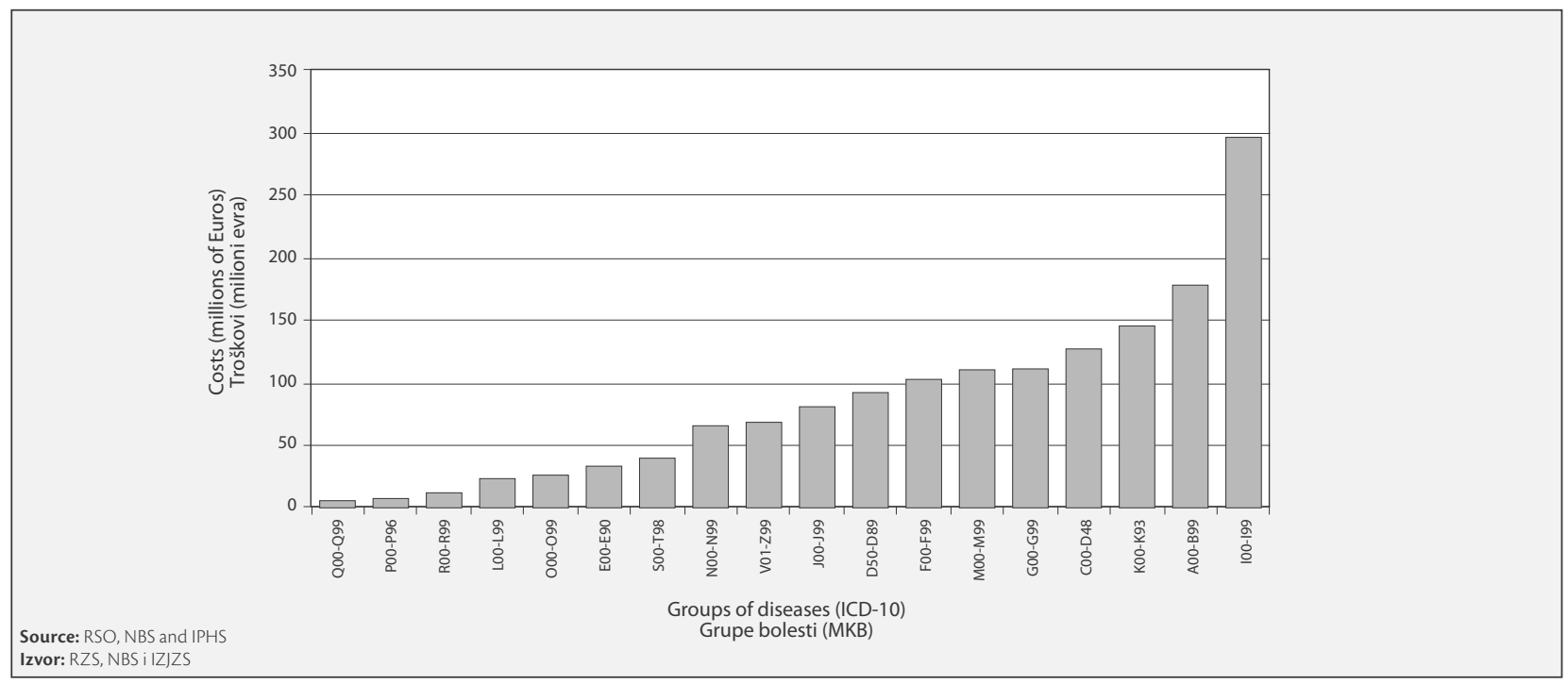

Graph 7. Costs in Euros for healthcare by ICD-10 groups in 2007

Grafikon 7. Troškovi zdravstvene zaštite prema grupama oboljenja MKB u 2007. godini izraženi u evrima

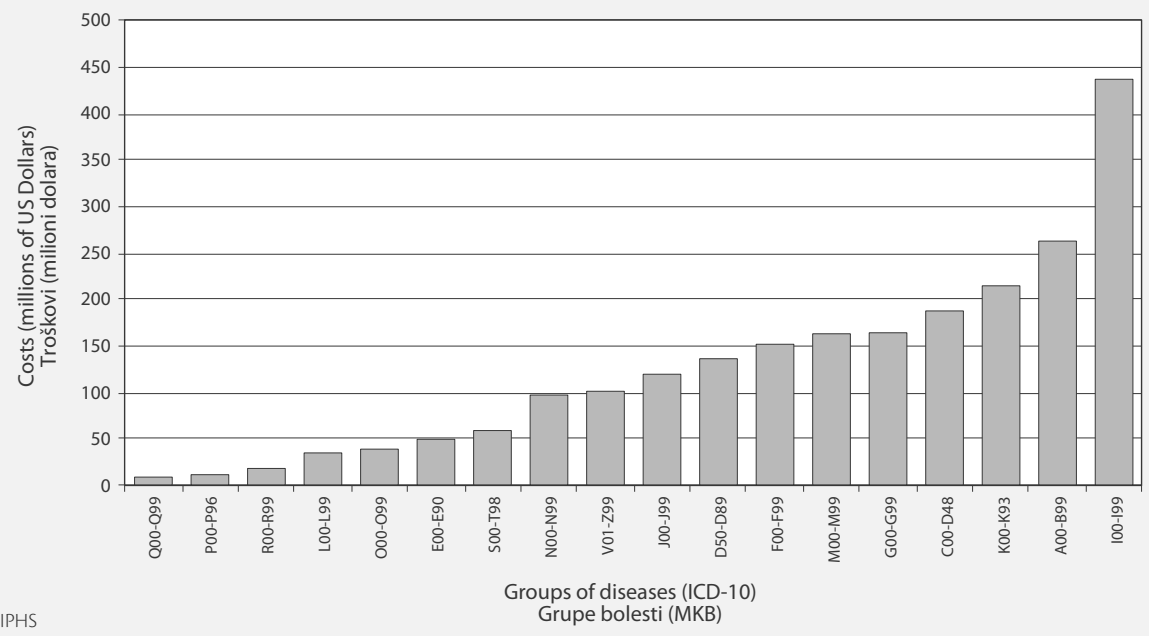

Graph 8. Costs in US dollars for healthcare by ICD-10 groups in 2007

Grafikon 8. Troškovi zdravstvene zaštite prema grupama oboljenja MKB u 2007. godini izraženi u američkim dolarima

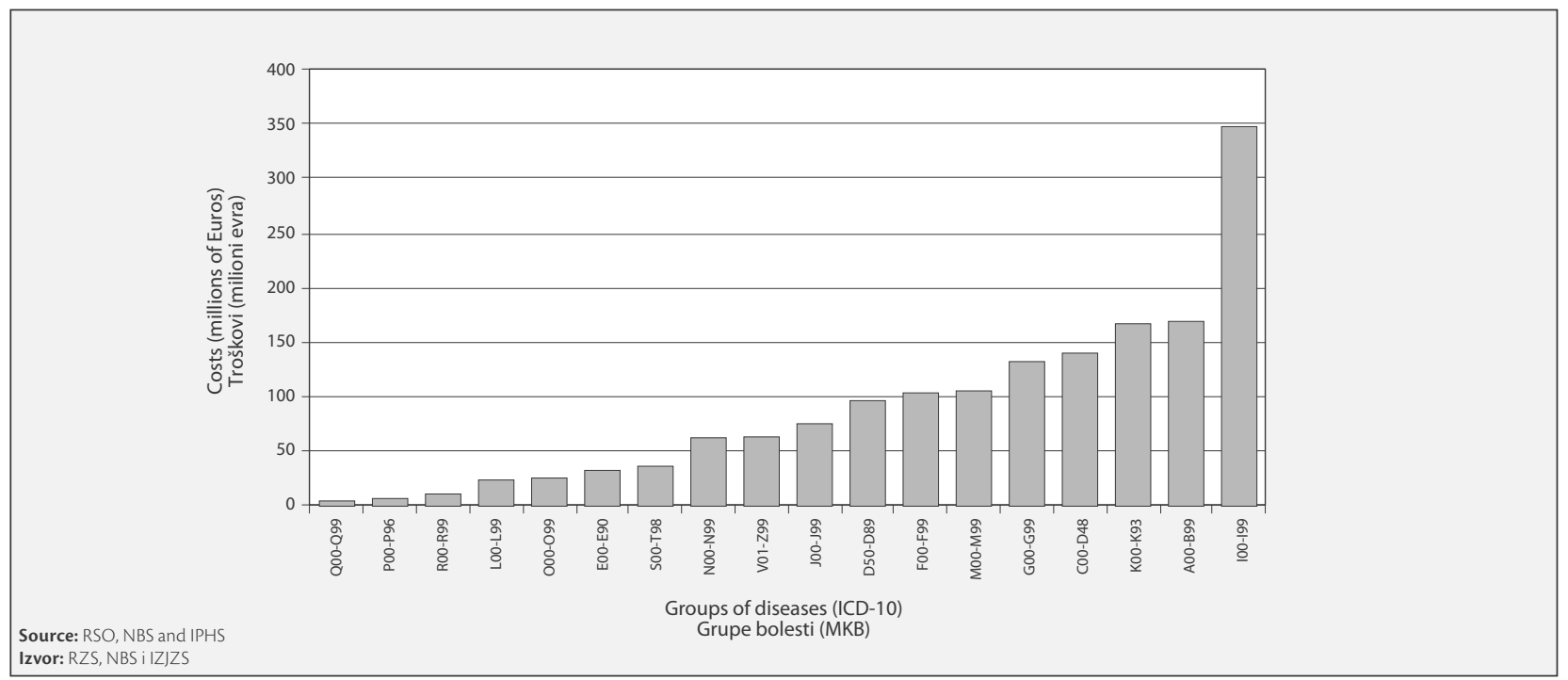

Graph 9. Costs in Euros for healthcare by ICD-10 groups in 2008

Grafikon 9. Troškovi zdravstvene zaštite prema grupama oboljenja MKB u 2008. godini izraženi u evrima 


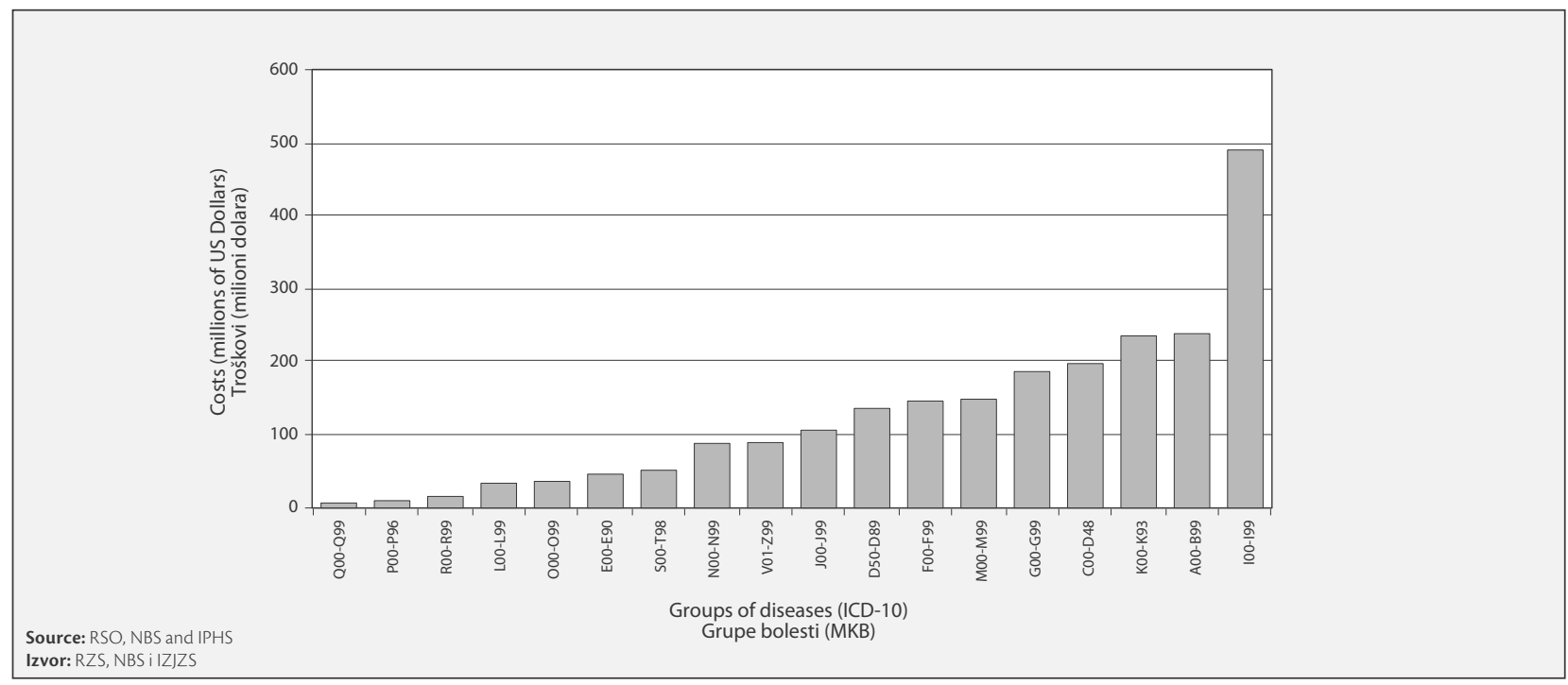

Graph 10. Costs in US dollars for healthcare by ICD-10 groups in 2008

Grafikon 10. Troškovi zdravstvene zaštite prema grupama oboljenja MKB u 2008. godini izraženi u američkim dolarima

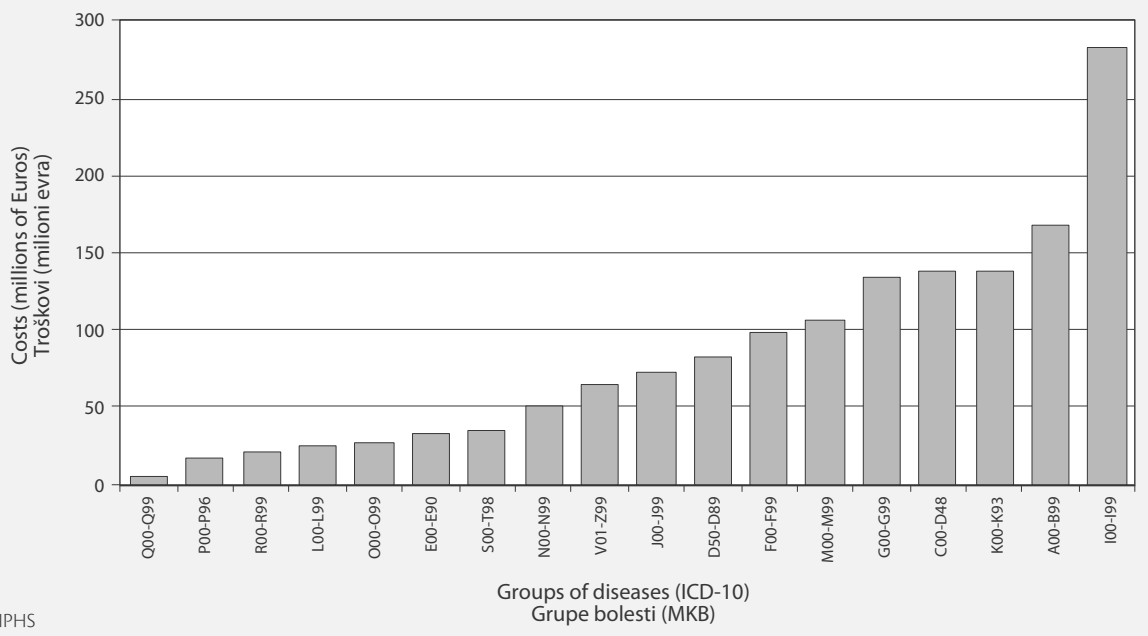

Source: RSO, NBS and IPHS

Graph 11. Costs in Euros for healthcare by ICD-10 groups in 2009

Grafikon 11. Troškovi zdravstvene zaštite prema grupama oboljenja MKB u 2009. godini izraženi u evrima

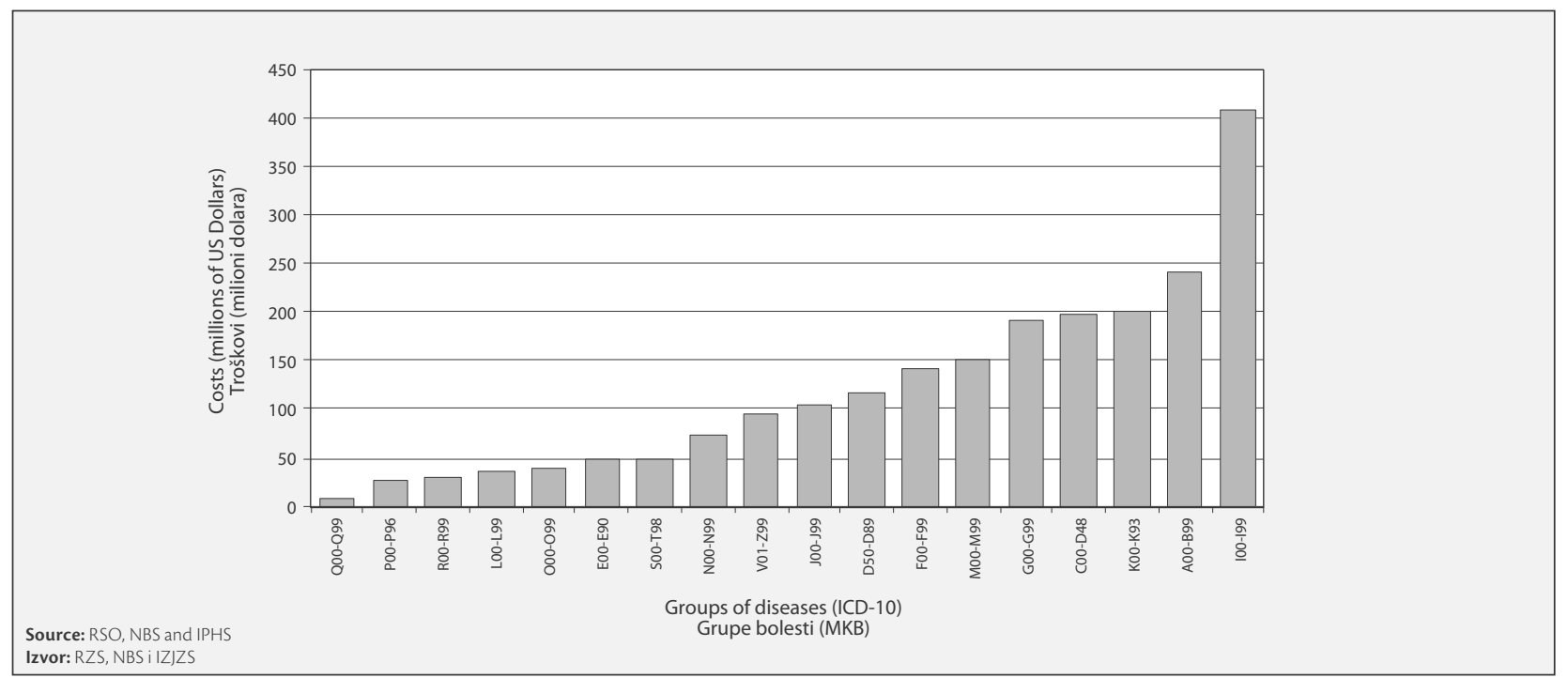

Graph 12. Costs in US dollars for healthcare by ICD-10 groups in 2009

Grafikon 12. Troškovi zdravstvene zaštite prema grupama oboljenja MKB u 2009. godini izraženi u američkim dolarima 


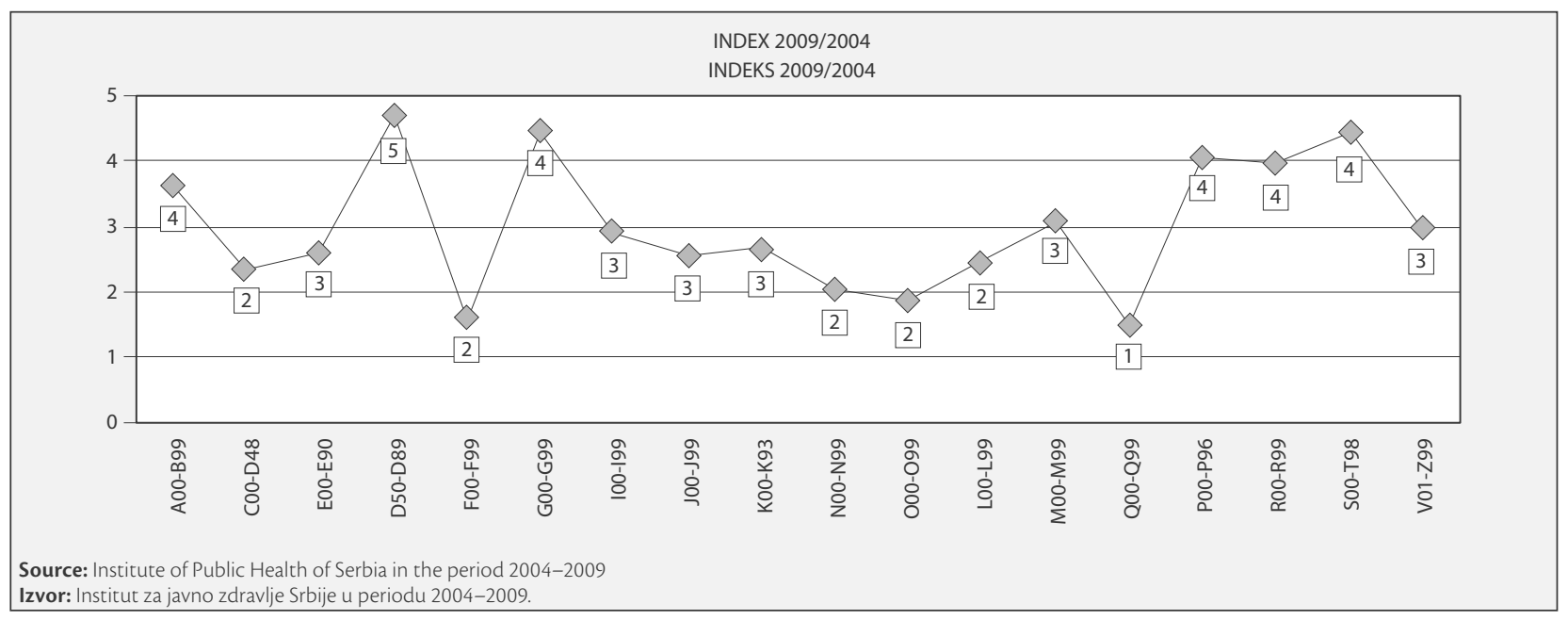

Graph 13. Growth index of financial resources by groups of diseases in the period 2004-2009

Grafikon 13. Indeks rasta finansijskih sredstava prema grupama oboljenja u periodu 2004-2009. godine

ICD-10 categories in 2004 per capita amounted $€ 83.76$, while the percentage of total costs in relation to the gross domestic product (GDP) for the year 2004 was $3.58 \%$.

The results showed that the health care cost by main ICD-10 categories in 2005 amounted 81,222,190,336.00 RSD ( $€ 949,967,138 ; \$ 1,124,666,678)$. As observed by groups of diseases, the highest costs were allocated to circulatory diseases (17.26\%), infectious and parasitic diseases (10.46\%), neoplasm (9.49\%) and urogenital system diseases (9.33\%), while the lowest allocated funds were for symptoms and pathological conditions $(0.92 \%)$, congenital anomalies $(0.61 \%)$ and prenatal conditions $(0.45 \%)$ (Graphs 3 and 4$)$. Total cost for health care by main ICD-10 categories per capita amounted to $€ 126.70$ in 2005, while the percentage of total expenditures relative to GDP for the same year was $4.81 \%$.

Total expenditure on health care by main ICD-10 categories in 2006 amounted 96,162,554,246.00 RSD ( $€$ $1,217,247,522 ; \$ 1,603,358,597)$. Observed by groups of diseases the highest amount of funds were allocated to circulatory diseases (20.14\%), infectious and parasitic diseases (11.64\%), digestive system diseases (9.87\%) and neoplasm (8.48\%), with the lowest funds allocated for symptoms and pathological conditions (0.95\%), congenital anomalies $(0.59 \%)$ and perinatal conditions (0.59\%) (Graphs 5 and 6). The analysis showed that cost of health care by main ICD-10 categories in 2006 per capita amounted to $€ 176.00$, while the percentage of total expenses in relation to GDP for 2006 amounts to $4.86 \%$.

Total expenditure on health care by main ICD-10 categories in 2007 amounted 120,987,502,236.00 RSD $(€ 1,526,922,066 ; \$ 2,251,868,727)$. Observed by groups of diseases the highest costs were allocated to circulatory diseases (19.42\%), infectious and parasitic diseases (11.67\%), digestive system diseases $(9.53 \%)$ and neoplasm $(8.33 \%)$, with the lowest allocation of funds to symptoms and pathological conditions (0.79\%), congenital anomalies $(0.49 \%)$ and perinatal conditions ( $0.37 \%)$ (Graphs 7 and 8). In 2007 the costs for health care by main ICD-10 categories per capita amounted to $€ 201.00$, while the percent- age of total expenses in relation to GDP for the same year was $5.12 \%$.

The results showed that the total costs for health care by main ICD-10 categories in 2008 amounted $142,398,620,728.00 \mathrm{RSD}(€ 1,607,189,769 ; \$ 2,263,889,041)$. Observed by groups of diseases the highest costs related to circulatory diseases (21.64\%), nervous system diseases (8.73\%), infectious and parasitic diseases (10.53\%), diseases of digestive system (10.40\%) and neoplasm (8.24\%), while the lowest costs related to symptoms and pathological conditions $(0.70 \%)$ and congenital anomalies (0.30\%) (Graphs 9 and 10). The analysis showed that cost of health care by main ICD-10 categories in 2008 per capita amounted to $€ 232.00$, while the percentage of total expenses in relation to GDP for the same year amounted to $5.04 \%$.

Total expenditure on health care by main ICD-10 categories in 2009 year amounted 144,150,456,906.00 RSD ( $€$ $1,633,396,861 ; \$ 2,160,253,219)$. Observed by groups of diseases the highest costs were for circulatory diseases $18.87 \%$, followed by infectious and parasitic diseases $11.20 \%$, diseases of digestive system of $9.26 \%$ and $8.88 \%$ for neoplasm and the lowest were for isolated congenital anomalies of $0.33 \%$ (Graphs 11 and 12). The analysis showed that costs of health care by main ICD-10 categories in 2009 per capita amounted to $€ 200.00$, while the percentage of total expenditures relative to GDP for 2009 amounted to $5.10 \%$.

The results showed that the greatest costs per groups of diseases in the period 2004-2009 were for circulatory diseases, and the lowest for congenital anomalies and perinatal conditions. The growth index funds by groups of diseases in this period showed the highest amount of funds within the period 2004-2009 allocated for blood diseases and they were increased five times, while funding for diseases of nervous system increased four times (Graph 13).

Health care expenditures by main ICD-10 categories per capita have a constant upward trend until 2008, whereas in year 2009 slight decline was recorded (Table 3). 
Table 3. Health care expenditures per capita from 2004 to 2009 Tabela 3. Troškovi zdravstvene zaštite po glavi stanovnika u periodu 2004-2009. godine

\begin{tabular}{|c|c|c|c|}
\hline \multirow{2}{*}{$\begin{array}{c}\text { Year } \\
\text { Godina }\end{array}$} & \multicolumn{3}{|c|}{$\begin{array}{c}\text { Expenditures per capita } \\
\text { Troškovi po glavi stanovnika }\end{array}$} \\
\cline { 2 - 4 } & $\begin{array}{c}\text { In RSD } \\
\text { U dinarima }\end{array}$ & $\begin{array}{c}\text { In Euros } \\
\text { U evrima }\end{array}$ & $\begin{array}{c}\text { In US Dollars } \\
\text { U dolarima }\end{array}$ \\
\hline 2004 & 6,608 & 83.76 & 114 \\
\hline 2005 & 10,833 & 126.7 & 150 \\
\hline 2006 & 12,825 & 176 & 213 \\
\hline 2007 & 16,136 & 201 & 300 \\
\hline 2008 & 18,992 & 232 & 302 \\
\hline 2009 & 19,225 & 200 & 288 \\
\hline
\end{tabular}

Sourse: NBS and IPHS Izvor: NBS i IZJZS

Table 4. Percentage of costs for health care in GDP from 2004 to 2009 Tabela 4. Procentualno učešće troškova zdravstvene zaštite u BDP u periodu 2004-2009. godine

\begin{tabular}{|c|c|c|}
\hline $\begin{array}{c}\text { Year } \\
\text { Godina }\end{array}$ & $\begin{array}{c}\text { GDP at current prices } \\
\text { (in million RSD) } \\
\text { BDP u tekućim cenama } \\
\text { (u milionima dinara) }\end{array}$ & $\begin{array}{c}\text { Share of assets } \\
\text { in GDP } \\
\text { Učešć sredstava } \\
\text { u BDP }\end{array}$ \\
\hline 2004 & $1,380,711.60$ & $3.58 \%$ \\
\hline 2005 & $1,683,483.30$ & $4.81 \%$ \\
\hline 2006 & $1,962,072.90$ & $4.86 \%$ \\
\hline 2007 & $2,302,214.40$ & $5.12 \%$ \\
\hline 2008 & $2,722,461.30$ & $5.04 \%$ \\
\hline 2009 & $2,815,000.00$ & $5.10 \%$ \\
\hline
\end{tabular}

Source: RSO and IPHS

IzVor: RZS i IZJZS

The percentage share of total costs for health care by main ICD-10 categories in GDP in the period 2004-2009 had continuous growth from $3.58 \%$ to $5.10 \%$ (Table 4 ).

\section{DISCUSSION}

A review of articles dealing with estimating cost of illness [1-7] have shown that studies usually covered some particular disease [8-16], injuries [17], disorders [18], or conditions [19-24]. Costs for health care by main groups of diseases are shown only in table 6 of SHA [25]. Many users of NHA tables have considered that Table 6, entitled "Health care costs according to the main groups of the International Classification of Diseases" (ICD-10 categories) was the most important and useful to decision makers. Although there is still no internationally accepted strict methodological instructions for making table 6 (except for the framework used in this study), international comparisons based on Table 6, although still very rare, started to appear [27]. International comparability is the main advantage of Table 6, while the main disadvantage is that the cost estimates in different countries vary in coverage and methodology of assessment, so the estimates are based on a set of assumptions and/or very small samples.

Total expenditures on health care in Serbia by main international classifications of disease in the period from 2004 to 2009 grew from 49,546,211,470.00 RSD in 2004 to $144,150,456,906.00 \mathrm{RSD}$ in year 2009. Costs per capita expressed in Euros in the period from 2004 to 2009 grew from 83.76 Euros per person in year 2004 to 232 Euros in 2008. In 2009, the costs were reduced to 200 Euros per person, which is explained by low value of Dinar to Euro in 2009. Expenditure per capita expressed in dollars in the observed period recorded the same trend growth.

Observed by groups of diseases the highest expenses in Serbia during period from 2004 to 2009 were for circulatory diseases (increased three times), and as compared to the increase in funding for other groups of diseases, showed the average growth. Financial resources for blood diseases during this period increased as much as 5 times, while for nervous system diseases they increased 4 times. The funds for infectious and parasitic diseases in this period increased four times, while for diseases of the musculoskeletal system increased 3 times.

When these costs were compared with findings from Australia, Canada, France, Germany and Netherlands [27] it was observed that in these countries circulatory diseases were credited for major expenses as well, probably as a consequence of modern life style. Unlike our country, where infectious and parasitic diseases proved the second highest consumption of financial funds in the observed period, followed by diseases of digestive system, nervous system diseases and neoplasm, in the above countries nervous system diseases proved to be the second largest consumer of financial resources, followed by diseases of digestive system, musculoskeletal system and neoplasm.

Observed by years, the total cost of health care by main ICD-10 categories showed the tendency of growth and was increased almost threefold, from 49,546,621,147.00 in year 2004, to $144,150,456,906.00$ in 2009. Faster growth of health care cost than growth of general public expenditures for health care in the same period, which increased from 82,335,000,000.00 in 2004 to $181,536,000,000.00$ in 2009 was recorded [28]. This fact speaks in favour of growing cost in the Republic of Serbia for the treatment of diseases over the years, and a reduction of investments in prevention, public health services, health administration, health insurance, as well as functions related to health care. The percentage in share of costs for health care by main ICD-10 categories in GDP in the period 2004-2009 increased from $3.58 \%$ to $5.10 \%$ in 2009 .

In 2004, the share of costs for health care by main ICD-10 groups in Serbia was $54.1 \%$ of the total cost for health care, while the share in Germany in the same year amounted $62 \%$ and in the Netherlands $60 \%$ [27]. There are no data available for other countries and other years, thus they are not comparable.

\section{CONCLUSION}

Comparative analysis showed the highest costs for health care in the period from 2004 to 200 in Serbia were allocated for circulatory diseases and overall spending in health care increased three times in 2009 as compared to 2004. 


\section{REFERENCES}

1. Rice DP. Cost of illness studies: what is good about them? Inj Prev. 2000; 6:177-9.

2. Kirschstein R. Disease-Specific Estimates of Direct and Indirect Costs of IIIness and NIH Support: Fiscal Year 2000 Update. Available from: http://ospp.od.nih.gov/ecostudies/COlreportweb.htm.

3. Bloom BS, Bruno Dj, Maman DY, Jayadevappa R. Usefulness of US costof-illness studies in healthcare decision making. Pharmacoeconomics. 2001; 19:207-13.

4. Goetzel RZ, Long SR, Ozminkowski RJ, Hawkins K, Wang S, Lynch W. Health absence, disability, and presenteeism cost estimates of certain physical and mental health conditions affecting U.S. employers. J Occup Environ Med. 2004; 46:398-412.

5. Segel JE. Cost-of-Illness Studies - A Primer. RTI International; 2006.

6. Honeycutt AA, Grosse SD, Dunlap LJ, Schendel DE, Chen H, Brann $E$, et al. Economic costs of mental retardation, cerebral palsy, hearing loss, and vision impairment. In: Altman BM, Barnartt SN, Hendershot G, Larson S, editors. Using Survey Data to Study Disability: Results from the National Health Interview Survey on Disability. London, England: Elsevier Science Ltd.; 2004. p.207-28.

7. Centers for Disease Control and Prevention (CDC). Economic costs associated with mental retardation, cerebral palsy, hearing loss, and vision impairment - United States, 2003. Morb Mortal Wkly Rep. 2004; 53:57-9.

8. Taylor DH Jr, Sloan FA. How much do persons with Alzheimer's disease cost Medicare? J Am Geriatr Soc. 2000; 48:639-46.

9. Begley CE, Annegers JF, Swann AC, Lewis C, Coan S, Schnapp WB, et al. The lifetime cost of bipolar disorder in the US: an estimate for new cases in 1998. Pharmacoeconomics. 2001; 19:483-95.

10. Begley CE, Famulari M, Annegers JF, Lairson DR, Reynolds TF, Coan $S$, et al. The cost of epilepsy in the United States: an estimate from population-based clinical and survey data. Epilepsia. 2000; 41:342-51.

11. Javitz HS, Ward MM, Watson JB, Jaana M. Cost of illness of chronic angina. Am J Manag Care. 2004; 10(11 Suppl):S358-69.

12. Lazar MA. How obesity causes diabetes: not a tall tale. Science. 2005; 307:373-5.

13. Lowell BB, Shulman GI. Mitochondrial dysfunction and type 2 diabetes. Science. 2005; 307:384-7

14. Hogan P, Dall T, Nikolov P; American Diabetes Association. Economic costs of diabetes in the US in 2002. Diabetes Care. 2003; 26:917-32.
15. Szucs TD, Berger K, Fisman DN, Harbarth S. The estimated economic burden of genital herpes in the United States. An analysis using two costing approaches. BMC Infectious Diseases. 2001; 1:5. (Available from: http://www.biomedcentral.com/content/ pdf/1471-2334-1-5.pdf)

16. Liu JL, Maniadakis N, Gray A, Rayner M. The economic burden of coronary heart disease in the UK. Heart. 2002; 88:597-603.

17. Currie G, Kerfoot KD, Donaldson C, Macarthur C. Are cost of injury studies useful? Inj Prev. 200; 6:175-6.

18. Swensen A, Birnbaum HG, Secnik K, Marynchenko M, Greenberg P, Claxton A. Attention-deficit/hyperactivity disorder: increased costs for patients and their families. J Am Acad Child Adolesc Psychiatry. 2003; 42:1415-23.

19. Yelin E, Trupin L, Cisternas M, Eisner M, Katz P, Blanc P. A national study of medical care expenditures for respiratory conditions. Eur Respir J. 2002; 19:414-21.

20. Yelin E, Herrndorf A, Trupin L, Sonneborn D. A national study of medical care expenditures for musculoskeletal conditions: the impact of health insurance and managed care. Arthritis Rheum. 2001; 44:1160-9.

21. Roux L, Donaldson C. Economics and obesity: costing the problem or evaluating solutions? Obes Res. 2004; 12:173-9.

22. Corso P, Grosse S, Finkelstein E. The skinny on COI analysis. Obes Res. 2004; 12:1189.

23. Flegal KM, Graubard BI, Williamson DF, Gail MH. Excess deaths associated with underweight, overweight, and obesity. JAMA. 2005; 293:1861-7.

24. Finkelstein EA, Fiebelkorn IC, Wang G. National medical spending attributable to overweight and obesity: how much and who's paying? Health Aff (Millwood). 2003; Suppl Web Exclusives:W3-219-26.

25. Ministarstvo zdravlja Republike Srbije i Republički zavod za statistiku. Sistem zdravstvenih računa: verzija 1.0; Beograd; 2005.

26. Republički zavod za zdravstveno osiguranje. Finansijski izveštaj RZZO za 2004, 2005, 2006, 2007, 2009. godinu. Beograd, mart 2004 2005, 2006, 2007, 2009.

27. Heijink R, Renaud T. Cost-of-illness studies: a five-country methodological comparison (Australia, Canada, France, Germany and the Netherlands). Questions d'économie de la Santé. 2009; (143):1-6.

28. Institut za javno zdravlje Srbije "Dr Milan Jovanović Batut". Zdravstveno-statistički godišnjak Republike Srbije, Beograd, 2004-2009.

Received: 23/03/2011 • Accepted: 25/05/2011 


\title{
Troškovi zdravstvene zaštite u Srbiji prema Međunarodnoj klasifikaciji bolesti za period 2004-2009. godine
}

\author{
Milena Gajić-Stevanović1, Snežana Dimitrijević1, Slavoljub Živkovićz, Nevenka Teodorović2, \\ Darinka Perišić-Rajnicke ${ }^{3}$ \\ 1Institut za javno zdravlje Srbije „Dr Milan Jovanović Batut”, Beograd, Srbija; \\ 2Stomatološki fakultet, Univerzitet u Beogradu, Beograd, Srbija; \\ ${ }^{3}$ CITY koledž, Univerzitet Šefild, Beograd, Srbija
}

\begin{abstract}
KRATAK SADRŽAJ
Uvod U okviru istraživanja troškova u sistemu zdravstvene zaštite poslednjih deset godina u svetu je sve veće interesovanje za izračunavanje troškova lečenja bolesnika. Ova vrednost je breme kojim određena bolest ili grupa oboljenja opterećuje društvo. Do 2000. godine, kada je Organizacija za ekonomski razvoj država (OECD) formirala Sistem zdravstvenih računa (SZR), nije postojalo okvirno metodološko uputstvo za izračunavanje cene lečenja bolesnika. Cilj ovog rada bio je da se utvrde troškovi zdravstvene zaštite u Srbiji prema Međunarodnoj klasifikaciji bolesti (MKB) od 2004. do 2009. godine.

Materijal i metode rada Urađena je retrospektivna i komparativna analiza zdravstvenih statističkih podataka iz baze Instituta za javno zdravlje Srbije i finansijskih podataka Republičkog zavoda za zdravstveno osiguranje za period 2004-2009. godine. Finansijski i podaci o uslugama bolničkog, ambulantnog i kućnog lečenja, pomoćnim uslugama zdravstvene zaštite, potrošnji lekova i potrošnih dobara u zdravstvu analizirani su primenom metodologije SZR.

Rezultati Tokom posmatranog perioda najveći trošakza zdravstvenu zaštitu ostvaren je 2009. godine, a iznosio je 144.150.456.906,00 dinara (1.503.321.134 evra; 2.160.253.219 američkih dolara), dok je najmanji ostvaren 2004. godine, a bio je 49.546.211.470,00 dinara (628.086.723 evra; 855.203 .134 američkih dolara). Te godine najveći deo troškova bio je izdvojen za lečenje od kardiovaskularnih bolesti $(18,98 \%)$ i tumora $(11,12 \%)$, a najmanji deo za lečenje osoba s urođenim anomalijama $(0,64 \%)$. U 2009. godini najveći deo sredstava utrošen je za lečenje od kardiovaskularnih oboljenja (18,87\%), infektivnih i parazitskih bolesti (11,20\%), oboljenja digestivnog sistema $(9,26 \%)$, bolesti nervnog sistema $(9,20 \%)$ i tumora $(8,88 \%)$, dok je najmanje novčanih sredstava izdvojeno za lečenje osoba s urođenim poremećajima (0,33\%).
\end{abstract}

Zaključak Komparativna analiza je pokazala da su se troškovi zdravstvene zaštite stanovnika Srbije od 2004. do 2009. godine povećali čak tri puta.

Ključne reči: Međunarodna klasifikacija bolesti; zdravstvena potrošnja; „koštanje” bolesti

\section{UVOD}

U okviru istraživanja troškova u sistemu zdravstvene zaštite poslednjih deset godina u svetu vlada sve veće interesovanje za izračunavanje troškova lečenja bolesnika [1-7]. Neke studije su obradile samo pojedine bolesti [8-16], povrede [17], poremećaje [18] ili stanja [19-24]. Troškovi zdravstvene zaštite predstavljaju breme kojim određena bolest ili grupa oboljenja opterećuje društvo [5]. Prve studije o novčanim iznosima lečenja od određenih bolesti ili grupa oboljenja pojavile su se 1950. godine, ali sve do 2000, kada je Organizacija za ekonomski razvoj država (Organisation for Economic Co-operation and Development - OECD) formirala Sistem zdravstvenih računa (SZR), nije postojalo ni okvirno metodološko uputstvo za izračunavanje cene lečenja bolesnika.

U tabeli broj 6 u SZR [25], kao delu Nacionalnog zdravstvenog računa (NZR), prikazani su tekući troškovi zdravstvene zaštite prema glavnim grupama oboljenja Međunarodne klasifikacije bolesti (MKB), koje su date u tabeli 1. U SZR su kao troškovi zdravstvene zaštite definisani svi oni troškovi u zdravstvenom sistemu koji ne uključuju prevenciju, usluge javnog zdravstva, zdravstvenu administraciju, zdravstveno osiguranje i troškove za vršenje funkcija u vezi sa zdravstvenom zaštitom.

Cilj ovog rada bio je da se utvrde troškovi zdravstvene zaštite stanovnika Republike Srbije prema glavnim grupama oboljenja MKB za period 2004-2009. godine.

\section{MATERIJAL I METODE RADA}

Urađena je retrospektivna i komparativna analiza zdravstvenih statističkih podataka iz baze Instituta za javno zdravlje Srbije (IZJZS) i finansijskih podataka Republičkog zavoda za zdravstveno osiguranje (RZZO) za period 2004-2009. godine. Finansijski i podaci o uslugama bolničkog, ambulantnog i kućnog lečenja, pomoćnim uslugama zdravstvene zaštite, potrošnji lekova i potrošnih dobara u zdravstvu analizirani su prema metodologiji SZR (verzija 1.0).

Troškovi zdravstvene zaštite stanovnika Srbije prema glavnim kategorijama MKB rađeni su po sledećoj shemi i metodologiji NZR i OECD:

- H.C.1. - usluge bolničkog lečenja su finansijski izražene tako što je broj bolničkih dana po grupama bolesti (izvor podataka: IZJZS) pomnožen sa cenom bolničkog dana iz važećeg Cenovnika zdravstvenih usluga RZZO [26];

- H.C.1.2. - usluge dnevne nege nisu registrovane po grupama bolesti (nije bilo podataka);

- H.C.1.3. - finansijska sredstva potrošena za ambulantno lečenje bolesnika dobijena su tako što je broj usluga ambulantnog lečenja (izvor podataka: IZJZS) pomnožen sa cenom iz važećeg Cenovnika zdravstvenih usluga RZZO;

- H.C.1.4. - usluge kućnog lečenja finansijski su izražene tako što su usluge kućnog lečenja (izvor podataka: planske tabele za domove zdravlja koje obrađuje IZJZS) pomnožene sa cenom iz važećeg Cenovnika zdravstvenih usluga RZZO; 
- H.C.4. - pomoćne usluge zdravstvene zaštite (laboratorijske analize, dijagnostika i prevoz bolesnika) finansijski su izražene tako što je iskustveno procenjen ukupan broj tih usluga pomnožen s odgovarajućim cenama iz važećeg Cenovnika zdravstvenih usluga RZZO;

- H.C.5.1. - finansijski prikaz utroška lekova i drugih potrošnih dobara dobijen je od Agencije za lekove i medicinska sredstva Srbije.

Zbir stavki H.C.1, H.C.1.2, H.C.1.3, H.C.1.4, H.C.4. i H.C.5.1. po grupama bolesti daje procenjenu finansijsku vrednost ukupne cene zdravstvene zaštite stanovnika Srbije prema grupama oboljenja MKB.

$\mathrm{U}$ analizi su primenjene komparativna i retrospektivna metoda istraživanja. Za analizu su korišćeni i podaci Republičkog zavoda za statistiku (RZS) i Narodne banke Srbije (NBS).

\section{REZULTATI}

Ukupna novčana sredstva (izražena u dinarima, evrima i američkim dolarima) koja su utrošena na zdravstvenu zaštitu stanovnika Srbije tokom šest posmatranih godina, prema glavnim grupama oboljenja MKB, prikazana su u tabeli 2. Analize za svaku godinu posebno prikazane su na grafikonima 1-12.

Ukupni troškovi zdravstvene zaštite u 2004. godini bili su skoro 50 milijardi dinara (oko 628 miliona evra; 855 miliona dolara). Posmatrano po grupama bolesti, najveća novčana sredstva izdvojena su za lečenje osoba s kardiovaskularnim oboljenjima $(18,98 \%)$, tumorima $(11,12 \%)$ i bolestima urogenitalnog sistema (10,02\%), dok je najmanje sredstava utrošeno za lečenje bolesnika s urođenim anomalijama $(0,64 \%)$ i perinatalnim stanjima $(0,86 \%)$ (Grafikoni 1 i 2). Troškovi zdravstvene zaštite po glavi stanovnika u 2004. godini iznosili su 83,76 evra, dok je udeo ukupnih troškova u bruto domaćem proizvodu (BDP) bio 3,58\%.

Ukupni troškovi zdravstvene zaštite u 2005. godini bili su nešto veći od 81 milijarde dinara (oko 950 miliona evra; oko milijardu i 125 miliona dolara). Posmatrano po grupama bolesti, najveća novčana sredstva izdvojena su za lečenje osoba s kardiovaskularnim oboljenjima (17,26\%), infektivnim i parazitskim bolestima (10,46\%), tumorima $(9,49 \%)$ i bolestima urogenitalnog sistema $(9,33 \%)$, dok je najmanje sredstava utrošeno na lečenje simptoma i patoloških stanja $(0,92 \%)$, urođenih anomalija $(0,61 \%)$ i perinatalnih stanja $(0,45 \%)$ (Grafikoni 3 i 4). Troškovi zdravstvene zaštite po glavi stanovnika u 2005. godini iznosili su 126,70 evra, dok je udeo ukupnih troškova u BDP bio 4,81\%.

Ukupni troškovi zdravstvene zaštite u 2006. godini bili su nešto veći od 96 milijardi dinara (1,22 milijarde evra; 1,6 milijardi dolara). Posmatrano po grupama bolesti, najveća novčana sredstva izdvojena su za lečenje osoba s kardiovaskularnim oboljenjima (20,14\%), infektivnim i parazitskim bolestima $(11,64 \%)$, bolestima digestivnog sistema $(9,87 \%)$ i tumorima $(8,48 \%)$, dok je najmanje sredstava utrošeno za lečenje simptoma i patoloških stanja $(0,95 \%)$, urođenih anomalija $(0,59 \%)$ i perinatalnih stanja $(0,59 \%)$ (Grafikoni 5 i 6). Troškovi zdravstvene zaštite po glavi stanovnika u 2006. godini iznosili su 176 evra, dok je udeo ukupnih troškova u BDP bio 4,86\%.

Ukupni troškovi zdravstvene zaštite u 2007. godini bili su 121 milijardu dinara (milijardu i po evra; 2,25 milijardi dolara). Posmatrano po grupama bolesti, najveća novčana sredstva izdvojena su za lečenje osoba s kardiovaskularnim oboljenjima $(19,42 \%)$, infektivnim i parazitskim bolestima $(11,67 \%)$, bolestima digestivnog sistema (9,53\%) i tumorima (8,33\%), dok je najmanje sredstava utrošeno za lečenje simptoma i patoloških stanja $(0,79 \%)$, urođenih anomalija $(0,49 \%)$ i perinatalnih stanja $(0,37 \%)$ (Grafikoni 7 i 8$)$. Troškovi zdravstvene zaštite po glavi stanovnika u 2007. godini iznosili su 201 evro, dok je udeo ukupnih troškova u BDP bio 5,12\%.

Ukupni troškovi zdravstvene zaštite u 2008. godini bili su nešto veći od 142 milijarde dinara (1,6 milijardi evra; 2,26 milijardi dolara). Posmatrano po grupama bolesti, najveća novčana sredstva izdvojena su za lečenje osoba s kardiovaskularnim oboljenjima $(21,64 \%)$, bolestima nervnog sistema $(8,73 \%)$, infektivnim i parazitskim bolestima (10,53\%), bolestima digestivnog sistema $(10,40 \%)$ i tumorima $(8,24 \%)$, dok je najmanje sredstava utrošeno za lečenje simptoma i patoloških stanja $(0,70 \%)$ i za lečenje osoba s urođenim anomalijama $(0,30 \%)$ (Grafikoni 9 i 10). Troškovi zdravstvene zaštite po glavi stanovnika u 2008. godini iznosili su 232 evra, dok je udeo ukupnih troškova u BDP bio 5,04\%.

Ukupni troškovi zdravstvene zaštite u 2009. godini bili su nešto veći od 144 milijarde dinara (1,63 milijarde evra; 2,16 milijardi dolara). Posmatrano po grupama bolesti, najveća novčana sredstva izdvojena su za lečenje osoba s kardiovaskularnim oboljenjima (18,87\%), infektivnim i parazitskim bolestima $(11,20 \%)$, bolestima digestivnog sistema $(9,26 \%)$ i tumorima $(8,88 \%)$, dok je najmanje sredstava utrošeno za lečenje osoba s urođenim anomalijama (0,33\%) (Grafikoni 11 i 12). Troškovi zdravstvene zaštite po glavi stanovnika u 2009. godini iznosili su 200 evra, dok je udeo ukupnih troškova u BDP bio 5,10\%.

Posmatrano po grupama bolesti, najveći troškovi zdravstvene zaštite u periodu 2004-2009. godine izdvojeni su za kardiovaskularne bolesti, a najmanji za urođene anomalije i perinatalna stanja. Kada se posmatra indeks rasta finansijskih sredstava po grupama bolesti u tom periodu, vidi se da su najveća sredstva izdvojena za lečenje osoba s kardiovaskularnim oboljenjima i da su se od 2004. do 2009. godine povećala pet puta, dok su novčana sredstva za lečenje od bolesti nervnog sistema povećana četiri puta (Grafikon 13).

Analiza je pokazala da su troškovi zdravstvene zaštite po glavi stanovnika imali stalni trend rasta do 2008. godine, da bi se u 2009. uočilo njihovo blago smanjenje (Tabela 3).

Udeo ukupnih troškova za zdravstvenu zaštitu u BDP od 2004. do 2009. godine pokazuje tendenciju rasta sa 3,58\% na $5,10 \%$ (Tabela 4).

\section{DISKUSIJA}

Pregledom istraživanja koja se bave troškovima lečenja bolesnika [1-7] uvidelo se da većina studija obrađuje samo pojedine bolesti [8-16], odnosno pojedinačne povrede [17], poremećaje [18] ili stanja [19-24]. Tekući troškovi zdravstvene zaštite prema glavnim grupama bolesti MKB predviđeni su da budu prikazani samo u tabeli 6 SZR, kao deo NZS [25]. Mnogi korisnici analiza NZS smatraju da je upravo tabela 6 u SZR, pod nazivom „Troškovi za zdravstvenu zaštitu po glavnim grupama Međunarodne klasifikacije bolesti” (kategorije MKB), najvažnija i najkorisnija donosiocima zdravstvene politike. Premda još ne postoji jasno opšteprihvaćeno metodološko uputstvo za izradu 
tabele 6 (osim okvirnog, koje je korišćeno i u ovom istraživanju), međunarodna poređenja na osnovu ove tabele, iako i dalje vrlo retka, ipak su počela da se vrše [27]. Upravo ta međunarodna uporedivost je glavna prednost tabele 6 . Njen nedostatak, međutim, jeste to što se procene troškova u različitim zemljama razlikuju u obuhvatu i metodologiji procene, tako da se zasnivaju na velikom skupu pretpostavki, odnosno veoma malim uzorcima.

Ukupni troškovi zdravstvene zaštite stanovnika Srbije prema glavnim oboljenjima MKB su se od 2004. do 2009. godine povećali sa oko 50 milijardi na skoro 150 milijardi dinara. Troškovi po glavi stanovnika izraženi u evrima takođe su se tokom posmatranog perioda povećali, i to sa 84 evra 2004. godine na 232 evra 2008. godine (skoro tri puta), da bi se 2009. smanjili na 200 evra, što se objašnjava posledicom oslabljene vrednosti dinara u odnosu na evro u 2009. godini. Troškovi po glavi stanovnika izraženi u dolarima tokom posmatranog perioda beleže iste promene.

Posmatrano po grupama bolesti, najveći troškovi zdravstvene zaštite u periodu 2004-2009. godine u Srbiji izdvojeni su za lečenje osoba s kardiovaskularnim oboljenjima, a tokom posmatranog vremenskog perioda povećali su se tri puta. To, u poređenju s rastom finansijskih sredstava za druge grupe bolesti, predstavlja srednji rast. Novčana sredstva za lečenje od kardiovaskularnih bolesti u pomenutom periodu povećala su se čak pet puta, za lečenje osoba s oboljenjima nervnog sistema i infektivnim i parazitskim bolestima četiri puta, a za bolesti mišićno-koštanog sistema tri puta.

Kada se rezultati ovih troškova uporede s nalazima iz Australije, Kanade, Francuske, Nemačke i Holandije [27], vidi se da se i u tim zemljama najveća sredstva u okviru zdravstvene zaštite izdvajaju za kardiovaskularna oboljenja, što je najverovatnije posledica današnjeg načina života. Za razliku od Srbije, gde se infektivne i parazitske bolesti nalaze na drugom mestu po potrošnji u posmatranom periodu, a prate ih bolesti digestivnog sistema, bolesti nervnog sistema i tumori, u pomenutim zemljama bolesti nervnog sistema se nalaze na drugom mestu po učešću finansijskih sredstava, a slede ih bolesti digestivnog sistema, koštano-mišićnog sistema i tumori.

Ukupni troškovi zdravstvene zaštite u Srbiji su se od 2004. do 2009. godine povećali tri puta, a beleže brži rast od rasta opštih javnih troškova za zdravstvenu zaštitu u istim godinama, koji su se povećali sa nešto više od 82 milijarde dinara u u 2004. na skoro 182 milijarde u 2009. godini [28]. Ta činjenica govori u prilog većim izdvajanjima u Republici Srbiji za lečenje bolesnika tokom godina, a smanjenju ulaganja u prevenciju, usluge javnog zdravstva, zdravstvenu administraciju, zdravstveno osiguranje i vršenje funkcija koje su u vezi sa zdravstvenom zaštitom. Udeo troškova zdravstvene zaštite u BDP u periodu 20042009 . godine povećao se sa $3,58 \%$ na 5,10\%. U 2004. godini troškovi zdravstvene zaštite prema kategorijama oboljenja MKB u Srbiji činili su 54,1\% ukupnih troškova za zdravstvenu zaštitu, dok su u Nemačkoj i Holandiji oni činili 62\%, odnosno 60\% ukupnih sredstava koja se izdvajaju za zdravstvo [27]. Podatke za ostale godine za druge zemlje nismo imali.

\section{ZAKLJUČAK}

Istraživanje je pokazalo da su najveća novčana sredstva u okviru troškova zdravstvene zaštite u periodu 2004-2009. godine u Srbiji izdvojena za lečenje osoba s oboljenjima kardiovaskularnog sistema, te da su se tokom šest posmatranih godina povećala tri puta. 